\title{
EFFECT OF FEEDING REGIME ON SKIN/LEATHER CHARACTERISTICS OF F1 CROSSBREED SHEEP IN THE HIGHLANDS OF ETHIOPIA
}

*Ayele Abebe

Debre-Birhan Agricultural Research, Ethiopia.

\section{ARTICLE INF O}

\section{Article history}

Received: December 03, 2019

Revised: March 10, 2020

Accepted: April 29, 2020

\section{Keywords}

Awassi

Bonga

Crossbreeding

Dorper

Leather

Skin quality

Washera
A B S T R A C T

This study was conducted to determine the effects of different levels of concentrate supplementation on the skin quality attributes of Awassi X Bonga (AB), Awassi X Washera (AW) \& Dorper X Menz (DM) crossbreed sheep. Forty-four lambs were assigned in to three-breed \& three-concentrate supplementation groups each based on body weight, randomly. Experimental animals were kept on natural pasture grazing dominated by Andropogon longipes grasses, the legume Trifolium species \& were supplemented 300,600- and 900-gram concentrate. The concentrate feed had $21 \%$ crude protein \& $14 \mathrm{MJ} / \mathrm{kg}$ metabolizable energy on a dry matter basis with a composition of $49.5 \%$ wheat bran, $49.0 \%$ Noug cake (Guizotia abyssinica), $1 \%$ limestone and $0.5 \%$ salt. After completion of the 90 days of experimental period, animals were slaughtered \& fresh skins were taken to the Leather Industry Development Institute (LIDI) for skin quality-related tests. Higher level of concentrate supplementation $(900 \mathrm{~g})$ significantly $(\mathrm{p}<0.05)$ improved skin weight, size, thickness \& tear load. However, supplementation level did not show significant difference $(\mathrm{p}>0.05)$ on moisture content at raw \& wet blue stage, fat content \& hide substance percentage. Except thickness, average tear load \& moisture content for raw skin, which was higher $(\mathrm{p}<0.05)$ for $\mathrm{DM}$ than $\mathrm{AB} \& \mathrm{AW}$, all physico-chemical tests were not significantly ( $p>0.05$ ) different among the breeds. Nevertheless, for some of the values of quality parameters, skins from DM, $900 \mathrm{~g}$ supplementation level are by far better. It can be concluded that skins from DM, AB \& AW, 300-900g concentrate supplementation levels in the diet improves production of leather that meet the acceptable range set by LIDI. Further studies on skin quality attributes including the high and lowland indigenous sheep breeds along with their different blood levels of cross breed is suggested.

*Corresponding Author: Ayele Abebe

Email: yemichaeld@gmail.com

(c) The Author(s) 2020.

\section{INTRODUCTION}

Ethiopia is endowed with a huge livestock species that are adapted to the different agro-ecologies. The country inhabits the second largest sheep population in Africa, numbering about 30.7 million heads (CSA, 2017). The country owns fourteen traditional sheep populations that are clustered into four major groups of sheep types based on their tail type namely, short fat-tailed, long fat- tailed, thin-tailed, and fat-rumped sheep, Galal, E.S.E (1983). Gizaw et al. (2007) used microsatellite DNA marker, nine breeds and six genetically distinct sheep breed groups were identified in the country being distributed in different agro-ecologies, production systems and ethnic groups. According to Gizaw et al. (2007), Washera, Bonga and Menz sheep are among the fourteen sheep breeds identified in Ethiopia adapted to 
the Western, South Western and Northern parts of the country, respectively. Small ruminants (sheep and goat) are among the livestock species having a unique behaviour requiring small investment, could be reproduced at a shorter cycle, have faster growth rates and sound environmental adaptability compared to the large ruminants. They require smaller investments to run the business compared to other livestock species. They are important protein sources in the diets of the poor and help to provide extra income and support survival for many farmers in the tropics and subtropics Legese (2014). Despite all the benefits obtained from sheep in Ethiopia, productivity per animal is very low. Most Ethiopian sheep breeds at the age of one year could not give more than $10 \mathrm{~kg}$ of carcass during slaughter Ayele and Urge (2019). The reason for this poor productivity could be attributed to the low feed availability in terms of quality and quality throughout the year, poor management, poor veterinary services and slow growth from adapted indigenous sheep breeds. Sheep improvement program in Ethiopia has primarily based on meat production. Several attempts were initiated to increase the productivity of indigenous sheep breeds in Ethiopia. Until recently, several improved exotic sheep breeds were imported to Ethiopia in different years to improve the productivity of indigenous sheep breeds by crossing to boost growth traits of the indigenous sheep breeds. Performance evaluation results from the on-station and on-farm (mainly based on Awassi pilot crossbreeding villages) showed that crossbreds often outperformed their local contemporaries (Getachew, Gizaw, Lemma and Taye, 2011). Indigenous sheep breeds particularly those from the Ethiopian highlands are reputed to have one of the best quality skins for leather products having fine natural qualities of clarity, thickness, flexibility, strength, and compact texture (Mahmud, 2000).

Skins of tropical sheep are generally thicker than those obtained from the layered structure of skins of finerwool breeds like Merino which gives them a poor reputation. Ethiopian hide and skin have good reputations in the international leather market for their unique natural substance of fitness, cleanness and compactness of texture, thickness, flexibility and strength (Leach, 1995).

It is hypothesized that importing exotic genotype for meat and milk production in native breeds might also affect important leather characteristics. Skins produced from crossbreed sheep in Ethiopia usually had less acceptance and sold at lower prices or are rejected completely (Getachew, Gizaw, Lemma and Taye, 2011). International trade of raw and manufactured hides, skins, and leather has grown at an average of $12 \%$ per annum over the past 30 years to around US $\$ 53.8$ billion (FAOSTAT, 2012). Since commodity trade patterns have changed, skin evaluation and classification have become necessary (FAO, 2010). Under Ethiopian condition, in order to maximize the benefits from the crossbreeding scheme, knowledge about the leather quality attributes of skins from crossbreed sheep is important. Therefore, the purpose of this experiment was to investigate the quality attributes of skins from the F1 cross breed sheep subjected to the different levels of concentrate supplementation in addition to grazing for the possible design of crossbreeding program in Ethiopia.

\section{MATERIALS AND METHODS \\ Description of the Study Site}

The study was conducted at the Debre Berhan Agricultural Research Center located in the central highlands of Ethiopia about $120 \mathrm{~km}$ north-east of Addis Ababa at an altitude of $2780 \mathrm{~m}$ above sea level and at a longitude of $390 \mathrm{E}$ and latitude $10 \mathrm{o} \mathrm{N}$. The grazing consists of natural vegetation dominated by Andropogon longipes grass with variable proportions of Pennisetum and Festuca spp. and the legume Trifolium spp. The climate is characterized by a long rainy season (JuneSeptember) accounting for $75 \%$ of the total rainfall, a short rainy season (February /March- April/May) and a dry season (October-January). The average annual rainfall at the centre is about $920 \mathrm{~mm}$. The average monthly minimum air temperature at $0.5 \mathrm{~m}$ above ground ranges from $2 \mathrm{oC}$ in November to $80 \mathrm{C}$ in August. The corresponding monthly maximum range from $18 \mathrm{oC}$ in September to $23 \mathrm{oC}$ in June. Hailstorms are not uncommon during the long rains while the dry seasons are often associated with night frosts.

\section{Experimental Animals and their Management}

The study involved 44 half-bred lambs; Awassi X Washera (AW), Awassi X Bonga (AB) and Dorper X Menz $50 \%$ (DM) male lambs. Dorper and Awassi sheep breeds were imported from the Republic of South Africa and Israel, respectively to improve the productivity of indigenous sheep breeds. Animals used in this study were a subset of animals produced from a large 
experiment aimed for the evaluation of early finishing ability of crossbreed ram lambs for commercial production. Experimental sheep were allocated into three treatment groups and three genotypes randomly after stratifying by age and initial live weight. Treatment groups were: grazing + supplemented with 300,600 and $900 \mathrm{~g} / \mathrm{d}$ concentrate feed (three genotype and three feeding levels). The average age of experimental sheep at the beginning of the experiment was 7.26 months and about 10 months during slaughtering. Experimental sheep weighed $23.92 \mathrm{~kg}$ at the commencement of the experiment. The concentrate feed was bought from Addis Ababa (Kality feed processing plant) and the feed had $21 \%$ crude protein and $14 \mathrm{MJ} / \mathrm{kg}$ metabolizable energy on a dry matter basis, having a composition of $49.5 \%$ wheat bran, $49.0 \%$ Noug cake (Guizotia abyssinica), $1 \%$ limestone and $0.5 \%$ salt. The experiment was conducted between May and July 2017. All animals were grazed together during the day time and supplemented their corresponding amount of concentrate feed in group basis twice a day at 12:00 am and during the night. Fresh skins from a total of 44 ram lambs of half-bred sheep having average 7.26 months of age and $23.99 \mathrm{~kg}$ initial weight at the beginning of experimentation were used for skin/leather quality (upper) attribute. The experiment consisted of 15 days of acclimatization and a fattening period of 90 days during which grazing was ad libitum and watering was twice a day. Experimental animals were drenched for internal parasites and dewormed for external parasites before the start of the experiment using the protocol used by the research centre.

\section{Skin Grading and Physical Test}

Fresh skin was taken for the analysis to the Leather Industry Development Institute (LIDI) the same day animals were slaughtered. Fresh skin weight was taken immediately after the animals were slaughtered. Fresh skin size measurement and quality grading were done at Leather Industry Development Institute Testing and Research Laboratory, Ethiopia (LIDI). Size of the skin was classified as medium, large and extra-large in square inch based on measurement for size by trained technicians in the institute. During wet salting, the procedure used was in accordance with Ethiopian standards authority. Before spreading the salt, skins were cleaned according to ESA code B. J6.003 (1990). The amount of salt used was $50 \%$ of the mass of fresh skin. Skins from all breeds were cured under the same conditions (wet salted) and tanned in the same manner (chrome tanned) so that differences between the varying groups are due to variations in the breed, diet and properties of the raw materials. The leather quality of ram lambs was then assessed for chemical and physicomechanical characteristics. Tensile strength in $\mathrm{N} / \mathrm{mm}^{2}$ and percent elongation (\%) was done according to the procedure of ISO 3376: 2011. Skin processing was performed according to the following main steps: soaking, liming, washing, fleshing, trimming, deliming, pickling, tanning, basification, slamming, neutralization, re-tanning, drying and smoothing. After tanning the leather were conditioned based on ISO 2419:2005 and sampling for the test was done based on the procedure of ISO 2418:2005. Environmental test condition was at a temperature of $20 \pm 2{ }_{0} \mathrm{C}$ and relative humidity of $65 \pm 5 \%$. Samples were taken parallel to the backbone and perpendicular to the backbone. The physical test gives an indication of the strength, as well as the amount of the leather, could be stretched before the upper grain layers crack, which will cause damage to the surface of leather. The following physical tests were implemented at LIDI.

\section{Tensile Strength}

Tensile strength is defined as the force required for the breaking of a dumbbell-shaped leather sample on the Instron machine. The sample is held firmly in two clamps. These two clamps move apart at a steady speed of $\pm 100 \mathrm{~mm} \mathrm{~min}^{-1}$. As they move apart, the force required to stretch the leather is measured automatically. At some point, the leather sample breaks. The force required to break the sample is called the tensile strength of the leather and is measured in Newton. For each test, samples cut along as well as across the length of the skin were used. Tensile strength was measured based on ISO 3376:2000 procedure.

Tensile strength $\left(\mathrm{N} / \mathrm{mm}^{2}\right)=\frac{\text { Measured breaking load }(\mathrm{N})}{(\text { Thickness }(\mathrm{mm}) \mathrm{X} \text { Width }(\mathrm{mm}))}$

\section{Elongation at Break}

This is measured during the tensile strength test described above. At the point of breaking, the leather has also been stretched. The percentage stretch is called the elongation at break. It is defined as the percentage stretch of the dumbbell-shaped leather sample before it broke. 
Elongation at break (\%)

$=\left(\frac{\text { Length at break }(\mathrm{mm})-\text { Initial length }(\mathrm{mm})}{\text { Initial length }(\mathrm{mm}))}\right) \times 100$

\section{Tear Load}

The test for slit tear strength involved a rectangular leather sample with a small slit cut in it. A clamp attached to its base and another clamp inserted through the slit then pulled the sample apart. The point at which the slit starts to tear was defined as the slit tear strength. The slit tear strength was expressed in relation to average leather thickness. Average tear load/arithmetic mean and tear resistance was determined using the test method of the International Organization for Standardization (ISO3377 2002) and (ISO3376 2000), respectively. Samples were conditioned according to IS02419 (2002). Sampling method and sampling location were according to ISO ISO2418 (2005) and IS02418 (2002), respectively. The thickness of the samples was in accordance with ISO2589 (2002).

Tear resistance $(\mathrm{N} / \mathrm{mm})=\left(\frac{\text { Force at tear }(\mathrm{N})}{\text { Skin thickness }(\mathrm{mm})}\right)$

\section{Double Edge Tear Force (N}

This is the highest load reached tear. Measured using ISO 3377-2:2002 procedure.

\section{Chemical Quality Test of Skin/Leather: Fat Content}

The fat content of the moisture-free samples was determined using a standard Soxhlet extraction method (IUC4 1998). The fat content was extracted from the samples by using the solvent dichloromethane. The process was allowed until the fat is completely extracted, at least for 5 hours. After the solvent was distilled from the flask, the extracted materials were dried at $102 \pm 2 \mathrm{oC}$ to constant weight. Samples were re-dried if the reduction in weight was more than $0.1 \%$ of its original weight. The total drying time was not allowed to exceed eight hours. The formula for determination of fat and other soluble substances by dichloromethane is as follows:

Extractable substance in $(\%)=\left(\frac{\text { g extract }}{\mathrm{g} \text { weight of the sample }}\right) \times 100$

\section{Moisture Content}

Moisture content, percent by mass of the skin samples was determined according to ES 1195 test method.

\section{Hide Substance (\%)}

The 'hide substance' $\mathrm{H}$, is expressed as a percentage by mass, is given by the formula: $\mathrm{H}=\mathrm{N} \times 5.62$. Where Nitrogen $(\mathrm{N})$ is expressed as a percentage by mass, is given by the formula;

$$
\mathrm{N}=\left(\frac{\mathrm{V}}{\mathrm{m}}\right) \times 0.7
$$

Where:

$\mathrm{V}$ is the volume, in milli litres, of the standard volumetric sulfuric or hydrochloric acid solution (5.5) used for the titration. Corrected for the blank test.

Table 1. Grading of raw skins in relation to mass and size for crossbred lambs based on specifications of the Ethiopian Quality Standards Agency (LSMEANS \pm SE).

\begin{tabular}{lcccc}
\hline Variable (n) & $\begin{array}{c}\text { Age } \\
(\text { months })\end{array}$ & $\begin{array}{c}\text { Initial Weight } \\
(\mathrm{kg})\end{array}$ & $\begin{array}{c}\text { Raw skin weight } \\
(\mathrm{kg})\end{array}$ & $\begin{array}{c}\text { Skin Size, Raw } \\
(\mathrm{Sq} f \mathrm{ft})\end{array}$ \\
\hline Overall (44) & $7.26 \pm 0.36$ & $23.92 \pm 1.39$ & $3.62 \pm 0.19$ & $7.75 \pm 0.30$ \\
Breed and blood level & $\mathrm{ns}$ & $\mathrm{Ns}$ & $* * *$ & $* *$ \\
Awassi x Bonga 50\% (10) & $7.1 \pm 0.45$ & $26.24 \pm 1.70$ & $4.23 \pm 0.23^{\mathrm{b}}$ & $8.54 \pm 0.36^{\mathrm{b}}$ \\
Awassi x Washera 50\% (13) & $7.6 \pm 0.36$ & $24.05 \pm 1.39$ & $3.74 \pm 0.19^{\mathrm{b}}$ & $8.11 \pm 0.30^{\mathrm{b}}$ \\
Dorper x Menz 50\% (21) & $7.2+0.29$ & $22.64 \pm 1.10$ & $3.14 \pm 0.15^{\mathrm{a}}$ & $7.05 \pm 0.23^{\mathrm{a}}$ \\
Treatment & $\mathrm{ns}$ & $\mathrm{Ns}$ & $* * *$ & $*$ \\
Grazing + 300 g concentrate (12) & $7.6 \pm 0.42$ & $23.85 \pm 1.60$ & $3.11 \pm 0.21^{\mathrm{a}}$ & $7.43 \pm 0.34^{\mathrm{a}}$ \\
Grazing + 600 g concentrate (16) & $7.0 \pm 0.33$ & $24.27 \pm 1.26$ & $3.57 \pm 0.17^{\mathrm{a}}$ & $7.74 \pm 0.27^{\mathrm{a}}$ \\
Grazing + 900 g concentrate (16) & $7.3 \pm 0.33$ & $24.81 \pm 1.26$ & $4.43 \pm 0.17^{\mathrm{b}}$ & $8.54 \pm 0.27^{\mathrm{b}}$ \\
CV (\%) & 18.03 & 20.91 & 18.53 & 13.71 \\
\hline
\end{tabular}

${ }^{* * *}=$ highly significant; ${ }^{* *}=$ moderately significant; ${ }^{*}=$ significant at $\mathrm{p}=0.05, \mathrm{~ns}=$ not significant at $\mathrm{p}=0.05$ and means with different subscript within a column are statistically different $(\mathrm{p}<0.05)$. 


\section{Data Recorded and Analysis}

Initial live weight, fortnightly weights and body condition scores were recorded for each experimental animal. Bodyweight was taken at the beginning, every 15 days and at the end of the $90^{\text {th }}$ day. Live weights and body condition scores were analyzed fitting a general linear model of SAS (2002), by fitting concentrate level as the main effect and initial age and weight as covariates. The covariate was kept in the model only when significant. Mean differences were tested using Tukey honest significant differences test.

\section{RESULTS AND DISCUSSION} Initial Age and Weight

The initial age and body weight of ram lambs used for this particular experiment was $7.26 \pm 0.19$ months and $23.92 \pm 1.39 \mathrm{~kg}$ were similar $(\mathrm{P}>0.05)$. Initial age in months and body weight in $\mathrm{kg}$ was indicated in Table 1.

\section{Raw Skin Weight and Size Grading of the Skin by Mass and Size}

The average raw skin weight and size was $3.62 \pm 0.19 \mathrm{~kg}$ and $7.75 \pm 0.30$ square feet, respectively. Raw skins from DM was significantly lower in weight and size $(p<0.05)$ than skins from $A B$ and AW. This is maybe attributed to the larger framed lambs born from Awassi rams compared to the short size meat breed of Dorper. According to the Ethiopian Specification for lambskin (code ES B.J6.003), the skins of all three-crossbreed sheep evaluated in the present experiment were categorized into extra-heavy (1.50-1.80 kg, standard) and extra-large group based on their mass and size. Contrary to our finding, Salehi et al. (2014), reported that they didn't get significant weight differences between goat types of Kashmir and Hairy goats. Since marketing of fresh skin is based on their mass and size the result obtained from our observation showed that skins from crossbreed sheep were of high value. Concentrate feeding level had also contributed to higher $(\mathrm{p}<0.05)$, raw skin weight and size in this particular experiment. Lambs fed on higher concentrate level $(900 \mathrm{~g} / \mathrm{h} / \mathrm{d})$ produced 42 and $15 \%$ more skin weight and size respectively, compared to their contemporary lambs fed on $300 \mathrm{~g}$ concentrate supplementation. This would imply, better feeding management could respond to a better size and weight of crossbreed sheepskin.

\section{Physical Characteristics of Leather Produced from Crossbreed Lambs Skin Thickness}

The skin thickness obtained from this particular study of the crossbreed lambs was better $(1.35 \mathrm{~mm}$ compared to the $0.6 \mathrm{~mm}$, standard). DM lambs produced $1.43 \mathrm{~mm}$ thick skin compared to $1.23 \mathrm{~mm}$ thickness produced from $\mathrm{AB}$ and $\mathrm{AW}$ crossbreed lambs. This indicates that sheepskin produced from crossbreed lambs fed on 300 $900 \mathrm{~g}$ concentrate supplementation on top of grazing is supper for upper leather production. Our finding is higher than the findings of Getachew et al. (2011), for indigenous Washera sheep $(0.99 \mathrm{~mm})$ and indigenous Menz sheep $(1.18 \mathrm{~mm})$ while it is comparable with the Awassi X Menz 50\% sheep (1.23mm).

Supplementation has a considerable effect $(\mathrm{p}<0.05)$ on the skin thickness; ram lambs supplemented $900 \mathrm{~g} / \mathrm{h} / \mathrm{d}$ produced skin thickness of $1.49 \mathrm{~mm}$ compared to the $1.17 \mathrm{~mm}$ thickness obtained from supplementation of $300 \mathrm{~g} / \mathrm{h} / \mathrm{d}$ signifying a thickness advantage of $27 \%$. A study made by Getachew et al. (2011) also showed a $19 \%$ advantage in thickness from better supplementation level on crosses and indigenous sheep breeds of Washera and Menz sheep.

\section{Tensile Strength}

Tensile strength obtained from this study ranged from 9.33 to $12.22\left(\mathrm{~N} / \mathrm{mm}^{2}\right)$, Table 1 . Our finding is lower than the tensile strength obtained by (Teklebrhan et al., 2012) (18.1-24.6 N/mm2) and (Getachew, Gizaw, Lemma and A., 2011) (16.11-18.94 N/ $\left.\mathrm{mm}^{2}\right)$. Breed and diet had no $(p>0.05)$ significant effect on tensile strength. The tensile strength obtained in this study is lower than the standard required $\left(20 \mathrm{~N} / \mathrm{mm}^{2}\right)$ for skins to be used for upper. However, all lamb breeds produced leather that had quality required by the leather industry (BASF, 2010). According to (BASF, 2010), the minimum tensile strength for lamb garment should be $12 \mathrm{~N} / \mathrm{mm}^{2}$.

\section{Elongation at Break}

Average elongation at break percentage in this study was 49.73 with the range of $46-51 \%$. No significant ( $p>0.05$ ) effect was observed among the treatment groups and genotypes tested for the percent elongation at break. Elongation at break 47, 50 and 51\% was recorded for $A B$, AW and DM sheep breeds, respectively. 
Table 2. Physical characteristics of leather produced from different genotype and feeding levels.

\begin{tabular}{|c|c|c|c|c|c|c|c|}
\hline Variable & $\begin{array}{l}\text { Average } \\
\text { thickness } \\
(\mathrm{mm})\end{array}$ & $\begin{array}{c}\text { Tensile } \\
\text { strength } \\
(\mathrm{N} / \mathrm{mm} 2)\end{array}$ & $\begin{array}{c}\text { Elongation } \\
\text { at break } \\
(\%)\end{array}$ & $\begin{array}{c}\text { Mean } \\
\text { tear load } \\
\text { Parallel to the } \\
\text { backbone }(\mathrm{N})\end{array}$ & $\begin{array}{c}\text { Mean } \\
\text { tear load } \\
\text { Perpendicular } \\
\text { to the back } \\
\text { Bone }(\mathrm{N})\end{array}$ & $\begin{array}{l}\text { Average } \\
\text { tear load } \\
(\mathrm{N})\end{array}$ & $\begin{array}{c}\text { Tear-Load } \\
(\mathrm{N} / \mathrm{mm})\end{array}$ \\
\hline Overall (44) & $1.35 \pm 0.08$ & $10.26+0.81$ & $49.73+1.73$ & $32.73+0.01$ & $36.72+0.45$ & $34.43+1.88$ & $27.03 \pm 1.32$ \\
\hline Breed & $*$ & ns & ns & ns & ns & * & ns \\
\hline Awassi x Bonga (10) & $1.23 \pm 0.09 \mathrm{a}$ & $12.11 \pm 1.05$ & $47.22 \pm 2.13$ & $35.14 \pm 4.42$ & $35.14 \pm 4.42$ & $32.57 \pm 3.87 \mathrm{ab}$ & $29.23 \pm 2.96$ \\
\hline Awassi x Washera (13) & $1.23 \pm 0.08 \mathrm{a}$ & $10.27 \pm 0.86$ & $49.51 \pm 1.73$ & $31.91 \pm 3.60$ & $31.31 \pm 3.60$ & $28.73 \pm 3.15 \mathrm{a}$ & $23.80 \pm 2.42$ \\
\hline Dorper x Menz (21) & $1.43 \pm 0.06 \mathrm{~b}$ & $9.33 \pm 0.68$ & $50.56 \pm 1.37$ & $39.84 \pm 2.84$ & $39.84 \pm 2.84$ & $37.58 \pm 2.49 \mathrm{~b}$ & $27.63 \pm 1.90$ \\
\hline Treatment & * & ns & ns & * & * & * & ns \\
\hline Grazing +300 g concentrate (12) & $1.17 \pm 0.09 \mathrm{a}$ & $10.31 \pm 0.69$ & $46.44 \pm 1.99$ & $23.28 \pm 3.72 \mathrm{a}$ & $30.31 \pm 4.15 \mathrm{a}$ & $26.32 \pm 3.63 \mathrm{a}$ & $25.03 \pm 2.78$ \\
\hline Grazing + 600 g concentrate $(16)$ & $1.28 \pm 0.07 \mathrm{ab}$ & $10.22 \pm 0.78$ & $50.00 \pm 1.57$ & $33.22 \pm 2.93 \mathrm{ab}$ & $32.98 \pm 3.26 \mathrm{~b}$ & $33.16 \pm 2.86 \mathrm{~b}$ & $26.19 \pm 1.19$ \\
\hline Grazing + 900 g concentrate (16) & $1.49 \pm 0.07 \mathrm{~b}$ & $11.18 \pm 0.78$ & $50.85 \pm 1.58$ & $37.66 \pm 2.94 \mathrm{~b}$ & $43.01 \pm 3.28 \mathrm{~b}$ & $39.41 \pm 2.87 \mathrm{~b}$ & $29.43 \pm 2.20$ \\
\hline
\end{tabular}

${ }^{* * *}=$ highly significant; ${ }^{* *}=$ moderately significant; ${ }^{*}=$ significant at $\mathrm{p}=0.05$, ns $=$ not significant at $\mathrm{p}=0.05$ and means with different subscript within a column are statistically different $(\mathrm{p}<0.05)$.

The average elongation at break percentage (47$51 \%)$ obtained for the three genotypes in our study is comparable to the results obtained by (Jacinto $e t$ al., 2011) (53\%) for the Texel $\times$ Native and Santa Inês $\times$ Native crossbreed sheep. $A$ trend of improvement seems to happen among the supplementation level $(46,50,51 \%)$ for the 300 , 600 and $900 \mathrm{~g}$ concentrate supplementation groups. This may indicate that higher supplementation would improve the physical test of the leather than the lower level of supplementation. (Getachew, Gizaw, Lemma and A., 2011) obtained 66 and $65 \%$ of elongation at break for the Awassi X Menz 50\%, Menz and Washera sheep breeds, respectively, which is slightly higher than our findings. A study made by (Teklebrhan et al., 2012) on Blackhead Ogaden, Hararghe Highland, Dorper X Blackhead Ogaden and Dorper $X$ Hararghe Highland exhibited percentage elongation of $48,56,52$, and $44 \%$, respectively indicating similar results with our study. The result obtained in this particular study is in the acceptable range $(40-80 \%)$ and recommended value for sheepskin signifying the products are fit for the use by the leather industry.

\section{Tear Load}

There was no significant effect $(p>0.05)$ on the mean tear load parallel to the backbone and perpendicular to the backbone in $(\mathrm{N})$. The average tear load (parallel and perpendicular) was $36.72 \mathrm{~N}$. Higher $(\mathrm{p}<0.05)$ average tear load was recorded for DM $(37.58 \mathrm{~N})$ compared to $(28.73 \mathrm{~N})$ for AW crossbred lambs. No significant ( $p>0.05$ ) difference was observed for tear load in $\mathrm{N} / \mathrm{mm}$ among the tested concentrate feeding levels and genotypes. Concentrate feeding level had considerable effects $(p<0.05)$ on average tear load parallel, average tear load perpendicular and average tear load for parallel and perpendicular to the backbone, respectively. A similar pattern of tear resistance was obtained by (Getachew, Gizaw, Lemma and A., 2011) notifying no influence on tear resistance by genotype and feeding levels. 
Tear resistance of 29.23, 23.80 and $27.63 \mathrm{~N} / \mathrm{mm}$ obtained for $A B, A W$ and $D M$, respectively, was better $(\mathrm{p}<0.05)$ than 15.01 to $15.99 \mathrm{~N} / \mathrm{mm}$ obtained for Awassi X Menz, Menz and Washera sheep breeds by (Getachew, Gizaw, Lemma and A., 2011) and was similar with Brazilian, South African and sheep breeds in Germany (Snyman and Jackson-Moss, 2000); (Oliveira et al., 2007).

\section{Chemical Characteristics of Leather Produced from Crossbreed Lambs Moisture Content for Raw Skin (\%)}

Moisture percent for raw and wet blue skin in percentage was indicated in Table 3 below. The average moisture content for raw and wet blue skin was 34 and $62 \%$, respectively. Breed of the sheep has a significant effect $(p<0.05)$ on moisture content for the raw skin. Moisture content for the skins from DM was lower compared to the $\mathrm{AB}$ and $\mathrm{AW}$ lambs. Concentrate supplementation levels did not $(p>0.05)$ affect the moisture content at the raw and wet blue level. Similarity, the moisture content at the wet blue stage was similar among the lamb breeds of $\mathrm{AB}, \mathrm{AW}$ and $\mathrm{DM}$, respectively. Moisture content obtained from different levels of concentrate supplementation (61-62\%) at the wet blue stage was slightly lower than the results of (Negussie et al., 2016) who obtained $69-74 \%$ for the Blackhead Ogden sheep finished on different feeding regimes.

\section{Hide Substance (\%)}

On average, the hide substance percent obtained in this study was 33 (Table 3). Lamb genotype and feeding regime didn't affect $(\mathrm{p}>0.05)$ the hide substance of the lambs' skin.

Table 3. Effects of feeding regime on leather chemical tests of AB, AW and DXM crossbred sheep.

\begin{tabular}{|c|c|c|c|c|}
\hline Variable & $\begin{array}{l}\text { Moisture Content } \\
\text { for RAW skin (\%) }\end{array}$ & $\begin{array}{c}\text { Moisture content } \\
\text { Wet blue (\%) }\end{array}$ & $\begin{array}{c}\text { Fat Content } \\
(\%)\end{array}$ & $\begin{array}{c}\text { Hide Substance } \\
(\%)\end{array}$ \\
\hline Overall (44) & $34.06 \pm 1.93$ & $61.48 \pm 0.68$ & $6.08 \pm 0.46$ & $32.46 \pm 1.33$ \\
\hline Breed & $* *$ & ns & Ns & ns \\
\hline Awassi x Bonga (10) & $44.16 \pm 3.83 b$ & $62.12 \pm 1.53$ & $5.06 \pm 1.06$ & $31.51 \pm 3.11$ \\
\hline Awassi x Washera (13) & $38.64 \pm 03.12 b$ & $63.09 \pm 1.25$ & $6.03 \pm 0.87$ & $32.16 \pm 2.54$ \\
\hline Dorper x Menz (21) & $27.42 \pm 02.46 \mathrm{a}$ & $60.20 \pm 0.99$ & $6.67 \pm 0.68$ & $33.16 \pm 2.00$ \\
\hline Treatment & ns & ns & Ns & ns \\
\hline Grazing + 300 g concentrate (12) & $42.03 \pm 3.59$ & $61.93 \pm 1.44$ & $6.26 \pm 0.99$ & $32.64 \pm 2.92$ \\
\hline Grazing + 600 g concentrate (16) & $33.33 \pm 2.83$ & $61.16 \pm 1.13$ & $6.11 \pm 0.78$ & $30.53 \pm 2.30$ \\
\hline Grazing + 900 g concentrate (16) & $34.85 \pm 2.84$ & $62.32 \pm 1.14$ & $5.39 \pm 0.79$ & $33.67 \pm 2.31$ \\
\hline
\end{tabular}

\section{Fat Content (\%)}

Sheepskin is expected to contain $30-40 \%$ natural fat and it affects the extent to which the leather accepts fat liquor substances with respect to the raw weight (Cassano et al., 2001) and degreasing operation is carried out to eliminate the excess fat substances. If natural fat is not sufficiently removed, it prevents the hydrophilic activities of chemicals (liquoring agents) and, therefore, some undesirable quality problems such as hardness to touch, loss of some physical strength, dyeing imperfection, and bad smells occurs in the finished product (Narayan, 2013). The present study revealed that, the fat content in all treatment groups was within the standard levels (4-10\%) for the upper shoe leather making. The average fat content of skin from this particular study was 6\%. Lamb genotype and feeding regime didn't affect ( $p>0.05)$ the fat content of the skins. The values obtained for fat content slightly decreased among the feeding regimes $(6.29,6.11$ and $5.39 \%)$ for 300,600 and $900 \mathrm{~g}$ concentrate supplementation indicating a higher level of concentrate level improves the quality of leather by reducing the fat content. Findings are comparable with those of (Haroun et al., 2014) as they obtained 6-7\% fat content for the Sudan Desert sheep, but lower than the fat content of the skins obtained by (Negussie et al., 2016), for Blackhead Ogaden sheep under different concentrate supplementation regime. However, our finding is higher than the values obtained by (Teklebrhan et al., 2012) for Hararghe highland, Black Head Ogaden, Dorper X 
Hararghe highland and Dorper X Blackhead Ogaden sheep. The amount of natural fat from different sides of the skin varies between $4-50 \%$ in sheepskins, $212 \%$ in cattle hides, and it depends on breed, age and sex of the animal (Bitilisli et al., 2004). In the tannery, the low-fat content of skin obtained after degreasing in $A B, A W$ and DM lamb breeds is an indication of better-quality leather agreeing with the works mentioned by (Sarkar, 1991).

\section{CONCLUSION AND RECOMMENDATIONS}

Concentrate supplementation levels had contributed to higher raw skin weight $(\mathrm{kg})$ and size in (square feet). Lambs fed on higher concentrate level $(900 \mathrm{~g} / \mathrm{h} / \mathrm{d}$ ) produced 42 and $15 \%$ more skin weight and size, respectively, compared to their contemporary lambs fed on $300 \mathrm{~g}$ supplementation. The skin thickness obtained from the crossbred lambs was better $(1.35 \mathrm{~mm}$ compared to the $0.60 \mathrm{~mm}$, standard). Supplementation has a considerable effect on the skin thickness; ram lambs supplemented $900 \mathrm{~g} / \mathrm{h} / \mathrm{d}$ produced skin thickness of $1.49 \mathrm{~mm}$ compared to the $1.17 \mathrm{~mm}$ thickness obtained from supplementation of $300 \mathrm{~g} / \mathrm{h} / \mathrm{d}$ signifying a thickness advantage of $27 \%$. On the other hand, DM lambs produced $1.43 \mathrm{~mm}$ thick skin compared to 1.23 mm thickness produced from $\mathrm{AB}$ and $\mathrm{AW}$ crossbreed sheep.

Tensile strength ranged from 9.33 to 12.22 (N/mm2). Breed and diet had no significant effect on tensile strength. Average elongation at break percentage in this study was 49.73 with the range of $46-51 \%$. Higher average tear load was recorded for DM $(37.58 \mathrm{~N})$ compared to $(28.73 \mathrm{~N})$ for AW crossbred lambs. The average fat content of skin from this particular study was $6 \%$. Lamb genotype and feeding regime did not affect the fat content of the skins. The values obtained for fat content is slightly decreased among the feeding regimes (6.29, 6.11 and 5.39\%) for 300, 600 and $900 \mathrm{~g}$ concentrate supplementation indicating a higher level of concentrate level improves the quality of leather by reducing the fat content. Lamb genotype and feeding regime did not affect the hide substance of the skins.

In conclusion, skins from crossbreed sheep like $\mathrm{DM}, \mathrm{AB}$, AW and demonstrated good skin quality attributes suited to the standards set by the Leather Industry Development Institute (LIDI) for sheepskins. Results from the current study revealed that skins from crossbred sheep (DM, AB and AW) could be potential both for meat and skin production for further benefit by the farmers, pastoralists and private sheep raisers in Ethiopia.

\section{ACKNOWLEDGEMENT}

The author is grateful to Debre-Birhan Agricultural Research Center and the Ethiopian Agricultural Research Institute (EIAR) for the financial support of the project and LIDI (Leather Industry Development Institute of Ethiopia) for analyzing the chemical and physical characteristics of skins. $\mathrm{He}$ also appreciates the assistances obtained from Mr. Asfaw Bisrat and Mr. Tesfaye Zewdie for their unreserved support.

\section{REFERENCES}

Ayele, S. and M. Urge. 2019. Productive and Reproductive Performances of Indigenous Sheep in Ethiopia: A Review. Open Journal of Animal Sciences, 09: 97-120.

BASF. 2010. Chelating agents: BASF opens Trilon M factory in Ludwigshafen Focus on Surfactants. HAPPI. Philips Parkway, Montvale, NJ. pp. 3.

Bitilisli, O., B. Behzat, S. Oscan, A. Ahmet and Z. Gokhan. 2004. Some Physical and chemical properties of Ostrich skins and leather. Indian Journal of Chemical Technology, , 11: 654-58.

Cassano, A., R. Molinari, M. Romano and E. Drioli. 2001. Treatment of aqueous effluents of the leather industry by membrane processes. Journal of Membrane Science, 181: 111-26.

CSA. 2017. Livestock and Livestock Characteristics Agricultural Sample Survey. Statistical Bulletin. Addis Ababa, Ethiopia. pp. 9-13.

FAO. 2010. World statistical compendium for hides, skins, leather and leather footwear.Tropical and Horticultural Products Service, Commodities and Trade Division (ESC). Food and Agriculture Organization of the United Nations: Rome.

FAOSTAT. 2012. Food and Agriculture Organization of the United Nations. Rome, Italy.

Getachew, T., S. Gizaw, S. Lemma and A. A. 2011. Quality parameters of skin from Menz, Awassi $\times$ Menz and Washera sheep breeds for leather production 5th annual regional conference on completed livestock research activities, Bahir Dar. Amhara Regional Agricultural Research Institute (ARARI). Bahir Dar, Ethiopia.

Getachew, T., S. Gizaw, S. Lemma and M. Taye. 2011. Breeding practices, growth, and carcass potential 
of fat-tailed Washera sheep breed in Ethiopia. Trop Anim Health Prod, 43: 1443-8.

Gizaw, S., J. A. Van Arendonk, H. Komen, J. J. Windig and O. Hanotte. 2007. Population structure, genetic variation and morphological diversity in indigenous sheep of Ethiopia. Animal Genetics, 38: 621-8.

Haroun, H. E., I. Y. Turki and M. A. Ebrahiem. 2014. The Effect of Breed on Skin/Leather Quality of Sudan Desert Sheep. Journal of Africa Leather and Leather Producuts Advances, 1: 45-53.

Jacinto, M. A. C., F. M. d. Vargas Junior, C. F. Martins, G. d. S. Pinto, F. A. Reis and A. R. d. Oliveira. 2011. Influence of genotype on the quality of sheep leather. Revista Brasileira de Zootecnia, 40: 1830-36.

Leach, I. 1995. Hides and skins for the tanning industry Food \& Agriculture Organizaion: Rome, Italy.

Legese, G. a. F., M. . 2014. Small ruminant value chain development in Ethiopia: Situation analysis and trends (International Center for Agricultural Research in the Dry Areas/International Livestock Research Institute., Trans.)ICARDA/ILRI Project Report. Nairobi, Kenya.

Mahmud, A. 2000. Development potential and constraints of hides and skins marketing in Ethiopia. In R.C. Merkel, G. Abebe and A.L. Goetsch (Eds.), The Opportunities and Challenges of Enhancing Goat Production in East Africa. Institute for Goat Research, Langston University,
Langston. Debub University, Awassa, Ethiopia. pp. 127-38.

Narayan, K. 2013. Green Approach to Leather Technology, MSC, Masters, University of Applied Science, Centria. Finland.

Negussie, F., M. Urge, Y. Mekasha and G. Animut. 2016. Effects of Different Feeding Regimes on Leather Quality of Finished Blackhead Ogaden Sheep. Science, Technology and Arts Research Journal, 4: 222.

Oliveira, R. J. F., R. G. Costa, W. H. Sousa, A. N. Medeiros, M. A. B. Dal Monte, D. Aquino and C. J. B. Oliveira. 2007. Influence of genotype on physicomechanical characteristics of goat and sheep leather. Small Ruminant Research, 73: 181-85.

Sarkar, K. 1991. Hide and skins processing technique. In, How to processing rawhide and skins in the tannery: ndian Leather Producer Association, Second Avenue, Mahatima Gandhi Road, Madrus, 60041, India.

Snyman, M. A. and C. A. Jackson-Moss. 2000. A comparison of leather properties of skins from ten different South African sheep breeds. South African Journal of Animal Science, 30.

Teklebrhan, T., M. Urge and Y. Mekasha. 2012. Carcass Measurement, Conformation and Composition of Indigenous and Crossbred (Dorper x Indigenous) F1 Sheep. Pakistan Journal of Nutrition, 11: 1055-60.

Publisher's note: EScience Press remains neutral with regard to jurisdictional claims in published maps and institutional affiliations.

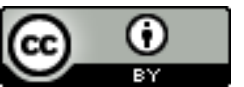

Open Access This article is licensed under a Creative Commons Attribution 4.0 International License, which permits use, sharing, adaptation, distribution and reproduction in any medium or format, as long as you give appropriate credit to the original author(s) and the source, provide a link to the Creative Commons license and indicate if changes were made. The images or other third-party material in this article are included in the article's Creative Commons license, unless indicated otherwise in a credit line to the material. If material is not included in the article's Creative Commons license and your intended use is not permitted by statutory regulation or exceeds the permitted use, you will need to obtain permission directly from the copyright holder. To view a copy of this license, visit http://creativecommons.org/licenses/by/4.0/. 